\title{
Chemical-instrumental-sensory parameters and chemometrics as tools to discriminate among the quality categories of dry-cured lberian shoulder
}

\author{
By A. Silva ${ }^{a, *}$, R. Reina ${ }^{a}$, J. García-Casco ${ }^{b}$ and J. Ventanas ${ }^{a}$ \\ ${ }^{a}$ Animal Source Foodstuffs Innovation Service (SiPA), University of Extremadura, Avda. Universidad s/n, \\ 10003 Cáceres \\ ${ }^{\mathrm{b}}$ INIA. Instituto Nacional de Investigación y Tecnología Agraria y Alimentaria, Zafra (Badajoz) \\ *Corresponding author: asilvaro@unex.es
}

\begin{abstract}
RESUMEN
Parámetros Químico-instrumental-sensoriales y quimiométricos como herramienta para discriminar entre las categorías de calidad de paletas lbéricas curadas

La combinación de determinaciones físico-químicas y sensoriales con herramientas quimiométricas han sido utilizadas para identificar la calidad de paletas Ibéricas curadas. Dependiendo del grado de confinamiento y la alimentación, tres clases de paletas Ibéricas curadas fueron analizadas: i) a partir de cerdos criados en régimen intensividad y alimentados con piensos comerciales (clase $\mathrm{CON}$ ), ii) a partir de cerdos criados en régimen de extensividad y alimentados con piensos comerciales (clase EXT) y iii) a partir de cerdos criados en régimen de extensividad y alimentados con recursos naturales (hierba y bellota) (clase MON, montanera). El análisis de componentes principales (PCA) permitió diferenciar entre tres tipos de paletas lbéricas curadas de acuerdo con su calidad. El modelo multivariante clasificatorio, Suave Modelado Independiente de Clases Analógicas (SIMCA), permitió caracterizar la calidad de paletas curadas cuya clase se desconoce. Finalmente, las representaciones gráficas de Cooman's y Si.vs.Hi permitieron la clasificación de la calidad de paletas Ibéricas curadas de calidad desconocida.
\end{abstract}

PALABRAS CLAVE: Calidad - Clasificación - Paletas curadas - PCA - SIMCA.

\section{SUMMARY}

Chemical-instrumental-sensory parameters and chemometrics as tools to discriminate among the quality categories of dry-cured lberian shoulder

A combination of physico-chemical and sensory measurements along with chemometric tools was used to authenticate the quality category of dry-cured Iberian shoulder. Depending on the confinement regime and feeding background, dry-cured lberian shoulders from three classes were analyzed: i) pigs reared in confinement regime and fed with commercial feeds (CON class), ii) pigs reared in extensive regime and fed with commercial feeds (EXT class) and iii) pigs reared in extensive regime and fed with natural sources (grass and acorns), called Montanera regime (MON class). The principal component analysis (PCA) results discriminated among the three types of dry-cured shoulders according to their quality. The soft independent modelling of class analogy (SIMCA), which is a classification model, enabled the characterization of the quality class of unknown dry-cured shoulder samples. Finally the Cooman's plot and
Si vs. Hi plot provide a classification for the unknown quality of dry-cured shoulders.

KEY-WORDS: Classification - Dry-cured shoulders $P C A$ - Quality - SIMCA.

\section{INTRODUCTION}

Iberian dry-cured meat products, like shoulders or hams have a high acceptance among consumers due to their particular sensory qualities. Recently, consumer demand for natural and traditional foods, such as meat products from Iberian pigs, has risen due to the effects of increasing concern for the environment, protection of the ecosystem, animal welfare, food safety and food quality properties (Ruiz et al., 2002, Ventanas et al., 2005, Ventanas, 2006). The Iberian pig is a breed of great economic importance in Spain and Portugal. According to the Spanish regulation of quality for Iberian meat and meat products, Iberian pig products should be derived from: i) crossed Iberian (Ib) x Duroc (Du), pigs normally reared in a confinement regime (CON) and fattened with commercial feed, and ii) pure Iberian, usually pigs reared in an extensive regime ("Montanera") (MON), in which traditionally pigs are fed according to the free-reared system during the final fattening period in an expanse of variable land area, using natural resources, grass (Quercus ilex) and acorns (Quercus suber), (García et al., 1991). Nevertheless, other pigs, normally pure Iberian, are fattened in a free-range system with commercial feeds, so that pigs may eat grass also, this feeding regime is known as "Extensive regime" (EXT) or campo. The Iberian cured products obtained from free-range pigs have gained wide consumer acceptance and have a high commercial value by virtue of their characteristic sensory quality. Moreover, these products can be considered healthy foods according to the new European regulation of "Healthy declarations" (CE regulation $n^{\circ}$ 432/2012) because of their high content in unsaturated fats and vitamins (B group), iron, selenium, etc. (Jiménez-Colmenero et al., 2010). The quality of dry-cured products, like ham 
and shoulder, depends directly on genetics (Ib $x$ Du or pure lberian) and on feeding and rearing regimes: CON, EXT, MON. However, there are other processing factors that affect final product quality, like salting time, and thermo-hygrometric conditions of the curing process (Ventanas et al., 2007). Analytical methods capable of discriminating among different rearing systems are needed to avoid fraudulent practices in the market. In Spain, the official method for discriminating among feeding and rearing regimes was established based on four fatty acids (FAs) of the subcutaneous fat from pigs (BOE, 2004). However, in recent years, new formulation feed enriched with high contents of oleic acid, mainly from sunflower, has been produced in order to mimic the fatty acid profile of pigs reared in the Montanera regime. In the order to avoid fraudulent practices at the market and mislead the final consumer, the Spanish Ministry of Agriculture had supported a project to look for an alternative analytical method to the fatty acid methods. Some methods based on neofitadiene analysis, triacylglycerol analysis, near infrared spectrometry (NIR), tocopherol analysis and chemical-sensor had been studied in the fat or muscle of Iberian pigs [INIA project RTA 2008-00026]. The same authors had studied different analytical techniques with chemometric tools to classify feeding regimes (Alonso et al., 2008, Narváez-Rivas et al., 2010, Gallardo et al., 2012) or food and beverages authentication (Jurado et al., 2007, Galeano-Díaz, et al., 2005)

In the framework of the INIA project, the chemical composition and the sensory quality of dry-cured shoulder from lberian pigs with three combinations of genetics and feeding and rearing regimes, which are found in the practice (IbxDu with CON regime, pure Iberian with EXT and MON regimes) were evaluated. The evaluation of the quality of these products is based on composition analysis using classic techniques and instrumental analysis (protein, fat, sodium chloride percentage, myoglobin, oxidation index, moisture, intramuscular fat, fatty acids and volatile compounds profile) and sensory analysis. This quality study had been made according to previous studies (Ventanas et al., 2007; Reina et al., 2012)

The aim of this work is to combine analytical parameters (physico-chemical and sensory parameters), related to the dry-cured shoulder quality, to create a data matrix and with chemometric tools, such as principal component analysis (PCA) and soft independent modelling of class analogy (SIMCA) providing the classification of known drycured shoulder quality.

\section{MATERIAL AND METHODS}

\subsection{Animal and samples}

The pigs used in this study were divided into three batches according to the feeding system at the end of the rearing period, as previously mentioned in the introduction. The CON feeding pigs were $50 \%$ Iberian and the other pigs of EXT and MON were of pure lberian. The provision of grass in the EXT group was quite high. The grass and acorns in the MON group were high enough for the MON regime pigs to gain $5 @$. The shoulders were cured in the Señorio de Montanera (Badajoz, Spain) for 14, 17 and 19 months for the CON, EXT and MON regimes, respectively. Other information, which is important for the interpretation of the results, has not been provided. The shoulders were removed from carcasses and kept under refrigeration before being subjected to the ripening process.

\subsection{Sample treatment}

Conformational measurements were carried out in each product: length, perimeter and width. Next, with an electric saw, two transverse cuts to each piece were made according to Reina et al. (2012). Random slices from the main muscles (Brachiocephalicus) were used for the sensory analysis. The rest of the sample was minced and homogenized, without subcutaneous or intermuscular fat, to carry out the rest of the analysis.

\subsection{Experimental design}

The study was carried out with two sets (calibration set and test set) of dry-cured shoulders. The calibration set was used to build the general PCA and PCA models for the SIMCA analysis and constituted 30 dry-cured shoulder from the three batches $(n=10)$ of pigs as previously described.

At the same time, a test set was used to validate the study and constituted 15 samples of unknown quality dry-cured shoulders CONO (2) and CON1; CON quality dry-cured shoulders from the same and from the previous year calibration samples, respectively were chosen. EXTO (2), EXT1 (2) and EXT2 (2): EXT quality dry-cured shoulder from extensive rearing pigs fed with normal, special 1 and special 2 feeding systems, respectively were also used. The special feeds were probably enriched with high oleic oils. Finally, MONO (2), MON1 (2) and MON2 (2); MON quality dry-cured shoulder were selected from the same (MON0) and from the previous year (MON1 and MON2, both from different MON) as the calibration samples.

\subsection{Analytical methods.}

\subsubsection{Physico-chemical analysis}

Before sectioning the dry-cured shoulder, they were morphologically characterized by length, width and perimeter measurements. All measurements were made in triplicate.

The physico-chemical analyses were divided in two sections: 
1. Proximate Composition: Moisture and salt contents were determined according to the Association of Official Analytical Chemists (AOAC, 2000) (moisture reference 935.29; salt content reference 971.19). Protein content was determined by the Kjeldahl method (AOAC, 2000). Intramuscular total lipids were extracted and quantified with chloroform/methanol $(2: 1, v / v)$ according to the method described by Folch et al., (1957). Haem pigments were assessed following the method described by Hornsey (1956).

2. Instrumental analysis: Lipid oxidation was analyzed using the 2-thiobarbituric acid (TBA) method of (Salih et al.,1987) using $2.5 \mathrm{~g}$ samples of dry-cured shoulder. TBA-reactive substance (TBARS) values were calculated from a standard curve of malondialdehyde (MDA) and expressed as $\mathrm{mg}$ MDA $\mathrm{kg}^{-1}$ meat. The fatty acid methyl esters (FAMEs) of the intramuscular fat were obtained by acidic transesterification following the method described by (Martin et al., 2008). Results were expressed as $\mathrm{mg}$ per $100 \mathrm{~g}$ of sample and as a percentage of each fatty acid relative to total fatty acids. Volatile compounds were extracted using the solid-phase microextraction (SPME) (Supelco Bellefonte, PA) fiber coated with carboxen-poly (dimethylsiloxane) (75 $\mu \mathrm{m}$ thickness) and subsequently analyzed by gas chromatography coupled to mass spectrometry (GC/MS) (gas chromatograph Hewlett-Packard 6890 series II coupled to a mass selective detector Hewlett-Packard HP-5973 A) following the method described by Jurado et al., (2009)

\subsubsection{Sensory analysis}

The samples were assessed by a trained panel of 12 members, using a quantitative-descriptive analysis method (QDA) (García et al., 1996) for seven different attributes (brightness, marbling, odor intensity, oiliness, flavor intensity, cured flavor, and rancid flavor).

Panelists had participated in a sensory evaluation of dry-cured products for several years. Three dry-cured shoulders from different batches were evaluated in each session. The sample order was randomized within the sessions. Two thin slices (1.0-1.5 mm) of each dry-cured shoulder were given to the panelist. At least one slice containing $1 \mathrm{~cm}$ of subcutaneous fat was given to each panelist. Slices were obtained using a commercial slicing machine and immediately served on glass plates. Both samples and plates were at room temperature $\left(20-23^{\circ} \mathrm{C}\right)$. A glass of water of about $200 \mathrm{~mL}$ at $12{ }^{\circ} \mathrm{C}$ was provided to each assessor. All sessions were done in a four booth sensory panel room at $22{ }^{\circ} \mathrm{C}$ equipped with white fluorescent lighting. The sensory traits, their definitions and extremes are explained in several works (Fulladosa et al., 2009; García et al., 1996; Ruiz et al., 1998). A FIZZ Network (version 1.01: Biosystemes, France) program was used for the sessions and the recording data obtained. The mean of all panelist scores for each attribute of each dry-cured shoulder was calculated to perform the statistical analysis.

\subsection{Data Analysis}

Treatment of anomalous data was carried out using the Grubbs test (Grubbs, 1969), as recommended by ISO rules. Data obtained from each analysis of the 30 samples were used as variables and the statistical analysis was carried out by ANOVA analysis of Variance using the statistical software package SPSS Version 15.0 (SPSS, 2006). The data were then subjected to a principal component analysis (PCA), which is a data compression method to reduce the dimensionality of the original data matrix by constructing Principal Components (PCs) that are linear combinations of the original variables and samples. The first PCs collected almost all of the variability in the original data. The supervised pattern recognition method with soft independent modelling of class analogy (SIMCA) based on the description of individual categories by means of the principal component analysis independent of mathematical models was used for the classification of samples of the unknown quality dry-cured shoulder. The statistical package UNSCRAMBLER (Unscrambler software, CAMO) was used for the application of PCA and SIMCA.

\section{RESULTS AND DISCUSSIONS}

In this study, several variables were measured and were used to build the PCA models and the SIMCA analysis: conformational parameters, such as length, width and perimeter, compositional and physicochemical parameters, such as moisture, protein, intramuscular fat, sodium chloride, myoglobin content, TBAs, fatty acid composition, volatile compounds and sensory features. Fattyacid composition, volatile compounds and sensory features are shown in tables 1,2 and 3, respectively. The measurement of many variables in different samples provided a large amount of data, so that a great deal of information was generated which is not easy to interpret. Fortunately, there are several tools that allow us to interpret this data, such as PCA, a multivariate technique that provides a determination of which aspect one sample is different from another.

The principle of PCA is finding the linear combinations of the initial variables that most contribute to making samples different from each other. These combinations are called principal components (PCs). Normally, the first PC carries the most information (more explained variance) and the second PC carries the maximum share of the residual information. The number of PCs is estimated by cross-validation, where variables that have a large standard deviation (SD) are weighted by the software and the PCA calculation 
Table 1

Fatty acid compositions from three quality groups, CON (from pigs normally reared confinement regime), EXT (from pigs reared in a free-range system with commercial feeds) and MON (from free-reared pigs fed during the final fattening period in a variable expanse of land, using natural resources, grass and acorns, and statistical analysis (ANOVA) between different groups

\begin{tabular}{|c|c|c|c|c|}
\hline Fatty Acids (\%) & CIN $(n=10)$ & $\operatorname{EXT}(n=10)$ & MON $(n=10)$ & $P^{A}$ \\
\hline C10:0 & $0,06^{a} \pm 0,03^{B}$ & $0,03^{b} \pm 0,01$ & $0,02^{b} \pm 0,01$ & *** \\
\hline C12:0 & $0,04 \pm 0,01$ & $0,04 \pm 0,02$ & $0,03 \pm 0,01$ & ns \\
\hline $\mathrm{C} 14: 0$ & $1,25 \pm 0,13$ & $1,30 \pm 0,36$ & $1,09 \pm 0,19$ & ns \\
\hline C14:1 & $0,03 \pm 0,01$ & $0,04 \pm 0,01$ & $0,04 \pm 0,01$ & ns \\
\hline C15:0 & $0,07^{a} \pm 0,01$ & $0,06^{a} \pm 0,01$ & $0,04^{b} \pm 0,00$ & 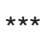 \\
\hline C15:1 & $0,08 \pm 0,01$ & $0,08 \pm 0,02$ & $0,05 \pm 0,01$ & ns \\
\hline C16:0 & $26,92 \pm 1,37$ & $26,12 \pm 1,30$ & $25,17 \pm 1,04$ & ns \\
\hline C16:1 & $4,11 \pm 0,74$ & $4,54 \pm 0,77$ & $3,79 \pm 0,80$ & ns \\
\hline C17:0 & $0,34^{a} \pm 0,03$ & $0,31^{a} \pm 0,03$ & $0,23^{b} \pm 0,03$ & *** \\
\hline C17:1 & $0,44^{\mathrm{a}} \pm 0,05$ & $0,39^{a} \pm 0,04$ & $0,26^{b} \pm 0,04$ & *** \\
\hline C18:0 & $10,54^{a} \pm 1,02$ & $8,86^{b} \pm 0,64$ & $9,75^{\mathrm{ab}} \pm 1,19$ & * \\
\hline C18:1 & $45,96^{a} \pm 0,78$ & $46,31^{a} \pm 1,13$ & $49,35^{b} \pm 1,19$ & *** \\
\hline C18:2(n-6) & $8,06 \pm 0,86$ & $8,64 \pm 0,44$ & $8,10 \pm 0,91$ & ns \\
\hline C18:3(n-6) & $0,03^{a} \pm 0,01$ & $0,05^{b} \pm 0,01$ & $0,05^{a} \pm 0,01$ & *** \\
\hline C18:3(n-3) & $0,41 a \pm 0,04$ & $0,69^{b} \pm 0,07$ & $0,51^{a} \pm 0,06$ & *** \\
\hline C20:0 & $0,11 \pm 0,01$ & $0,11 \pm 0,03$ & $0,12 \pm 0,02$ & ns \\
\hline C20:1 & $0,61 \pm 0,11$ & $0,60 \pm 0,10$ & $0,61 \pm 0,05$ & ns \\
\hline C20:2 (n-6) & $0,25 \pm 0,04$ & $0,26 \pm 0,05$ & $0,23 \pm 0,02$ & ns \\
\hline C20:3 (n-6)+C21 & $0,11^{a} \pm 0,01$ & $0,10^{a} \pm 0,02$ & $0,08^{b} \pm 0,02$ & *** \\
\hline C20:4 (n-6) & $0,59 \pm 0,08$ & $0,60 \pm 0,04$ & $0,57 \pm 0,14$ & ns \\
\hline C20:3(n-3) & $0,06^{a} \pm 0,01$ & $0,09^{b} \pm 0,00$ & $0,07^{\mathrm{a}} \pm 0,01$ & 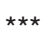 \\
\hline C20:5(n-3) & $0,02^{\mathrm{a}} \pm 0,00$ & $0,04^{b} \pm 0,01$ & $0,03^{a} \pm 0,01$ & *** \\
\hline C22:0 & $0,02 \pm 0,00$ & $0,02 \pm 0,01$ & $0,01 \pm 0,01$ & ns \\
\hline C22:1 & $0,02 \pm 0,00$ & $0,02 \pm 0,01$ & $0,01 \pm 0,00$ & ns \\
\hline C22:2 & $0,02 \pm 0,00$ & $0,02 \pm 0,01$ & $0,02 \pm 0,00$ & ns \\
\hline C23:0 & $0,08^{a} \pm 0,01$ & $0,07^{\mathrm{a}} \pm 0,02$ & $0,05^{b} \pm 0,01$ & *** \\
\hline $\mathrm{C} 24: 0$ & $0,02^{\mathrm{a}} \pm 0,00$ & $0,02^{a} \pm 0,01$ & $0,01^{b} \pm 0,00$ & ** \\
\hline C22:6(n-3) & $0,06 \pm 0,01$ & $0,08 \pm 0,02$ & $0,07 \pm 0,02$ & ns \\
\hline C24:1 & $0,01 \pm 0,00$ & $0,02 \pm 0,01$ & $0,02 \pm 0,01$ & ns \\
\hline SFA & $39,44^{a} \pm 1,44$ & $36,93^{b} \pm 1,47$ & $36,52^{b} \pm 1,24$ & * \\
\hline MUFA & $51,25^{a} \pm 0,87$ & $52,01^{a} \pm 1,08$ & $54,13^{b} \pm 1,11$ & *** \\
\hline PUFA & $9,49 \pm 1,00$ & $10,47 \pm 0,50$ & $9,63 \pm 0,98$ & ns \\
\hline$n-6$ & $8,93 \pm 0,96$ & $9,56 \pm 0,47$ & $8,94 \pm 0,99$ & ns \\
\hline$n-3$ & $0,55^{a} \pm 0,05$ & $0,89^{b} \pm 0,07$ & $0,67^{a} \pm 0,08$ & *** \\
\hline MUFA/SFA & $1,30^{a} \pm 0,06$ & $1,44^{b} \pm 0,08$ & $1,48^{b} \pm 0,07$ & ** \\
\hline
\end{tabular}

${ }^{A}$ statistical significance: ${ }^{* * *}, * *,{ }^{*}$ significance levels at $<0.001,<0.01,<0.05$, respectively.

${ }^{B}$ mean \pm standard deviation.

a, b, c, means with different superscript differ significantly.

is performed by standardization and used to equilibrate the same variance for all variables. The PCA model is characterized by loadings, which describe the data structure in terms of variables and scores, which describe properties, differences or similarities among the samples. In this case, as 
Table 2

Volatile compounds from three quality groups, CON class (from pigs normally reared in confinement regime, EXT class (from pigs reared in a free-range system with commercial feeds) and MON class (from free-reared pigs fed during the final fattening period in a variable expanse of land, using natural resources, grass and acorns), and statistical analysis (ANOVA) between different groups

\begin{tabular}{lcccc}
\hline \multicolumn{1}{c}{ Volatile compounds } & CON $(\mathbf{n}=10)$ & EXT $(\mathbf{n}=10)$ & MON $(\mathbf{n}=10)$ & $\mathbf{P}^{\mathrm{A}}$ \\
\hline 2,3-butanodione & $0,59 \pm 0,16^{\mathrm{B}}$ & $0,78 \pm 0,35$ & $1,10 \pm 0,46$ & $\mathrm{~ns}$ \\
3-metilbutanal & $18,98^{\mathrm{a}} \pm 14,67$ & $14,64^{\mathrm{a}} \pm 11,42$ & $31,58^{\mathrm{b}} \pm 12,98$ & $*$ \\
2-metil butanal & $8,04 \pm 5,82$ & $7,42 \pm 5,65$ & $13,10 \pm 10,26$ & $\mathrm{~ns}$ \\
Pentanal & $14,19 \pm 5,70$ & $10,21 \pm 6,83$ & $13,31 \pm 9,44$ & $\mathrm{~ns}$ \\
Hexanal & $67,98^{\mathrm{a}} \pm 22,96$ & $32,26^{\mathrm{b}} \pm 12,84$ & $33,89^{\mathrm{b}} \pm 14,44$ & $* * *$ \\
2-heptanone & $23,72^{\mathrm{b}} \pm 7,18$ & $5,84^{\mathrm{a}} \pm 4,18$ & $6,00^{\mathrm{a}} \pm 4,42$ & $* * *$ \\
Heptanal & $6,05^{\mathrm{a}} \pm 2,80$ & $1,23^{\mathrm{b}} \pm 0,42$ & $2,25^{\mathrm{b}} \pm 1,32$ & $* * *$ \\
Dihidro-5-metil-2(3H)-furanone & $0,68 \pm 0,28$ & $0,38 \pm 0,22$ & $0,46 \pm 0,22$ & $\mathrm{~ns}$ \\
2-pentilfurane & $2,70^{\mathrm{a}} \pm 1,24$ & $0,49^{\mathrm{b}} \pm 0,24$ & $0,47^{\mathrm{b}} \pm 0,18$ & $* * *$ \\
Octanal & $3,07^{\mathrm{a}} \pm 1,34$ & $0,78^{\mathrm{b}} \pm 0,43$ & $0,4^{\mathrm{b}} \pm 0,32$ & $* * *$ \\
Dihidro-5-etil-2(3H)-furanona & $1,73^{\mathrm{a}} \pm 0,63$ & $0,36^{\mathrm{b}} \pm 0,24$ & $0,70^{\mathrm{b}} \pm 0,46$ & $* * *$ \\
Nonanal & $1,87 \pm 0,91$ & $0,42 \pm 0,30$ & $1,63 \pm 1,59$ & $\mathrm{~ns}$ \\
Decanal & $0,51^{\mathrm{a}} \pm 0,33$ & $0,11^{\mathrm{b}} \pm 0,04$ & $0,39^{\mathrm{a}} \pm 0,24$ & $* * *$ \\
Dihidro-5-butil-2(3H)-furanona & $0,46 \pm 0,21$ & $0,14 \pm 0,10$ & $0,58 \pm 0,42$ & $\mathrm{~ns}$ \\
AA & $29,90^{\mathrm{a}} \pm 19,91$ & $22,94^{\mathrm{a}} \pm 17,12$ & $46,42^{\mathrm{b}} \pm 12,88$ & $*$ \\
LIPIDS & $120,99^{\mathrm{a}} \pm 39,85$ & $52,23^{\mathrm{b}} \pm 32,21$ & $58,16^{\mathrm{b}} \pm 26,43$ & $* * *$ \\
AA/LIPIDS & $0,28^{\mathrm{a}} \pm 0,23$ & $0,53^{\mathrm{ab}} \pm 0,29$ & $0,89^{\mathrm{b}} \pm 0,31$ & $*$ \\
\hline
\end{tabular}

${ }^{\text {A }}$ statiscial significance: $* * *, * *,{ }^{*}$ significance levels at $<0.001,<0.01,<0.05$, repectively

${ }^{\mathrm{B}}$ peak mean area $\left(\right.$ uaa $\left.\times 10^{6}\right) \pm$ standard deviation

$a, b, c$, means with different superscript differ significantly

Table 3

Sensory features from three quality groups, CON class, EXT class and MON class, and statistical analysis (ANOVA) between different groups

\begin{tabular}{llrrrr}
\hline \multicolumn{2}{c}{ Sensory features } & CON $(\mathbf{n}=10)$ & EXT $(\mathbf{n}=10)$ & MON $(\mathbf{n = 1 0})$ & $\mathbf{P}^{\mathbf{A}}$ \\
\hline Appearance & Brightness & $5,34^{\mathrm{a}} \pm 1,19$ & $6,27^{\mathrm{ab}} \pm 0,61$ & $6,68^{\mathrm{b}} \pm 0,39$ & $* *$ \\
& Marbling & $1,92 \pm 0,57$ & $2,41 \pm 0,92$ & $1,91 \pm 0,28$ & $\mathrm{~ns}$ \\
\multirow{2}{*}{ Odor } & intensity & $5,75 \pm 0,48$ & $6,25 \pm 0,12$ & $6,14 \pm 0,27$ & $\mathrm{~ns}$ \\
Fat Texture & Oiliness & $6,35^{\mathrm{a}} \pm 0,97$ & $6,88^{\mathrm{ab}} \pm 0,64$ & $7,27^{\mathrm{b}} \pm 0,63$ & $* *$ \\
Flavor & intensity & $6,35^{\mathrm{a}} \pm 0,16$ & $6,31^{\mathrm{a}} \pm 0,24$ & $6,56^{\mathrm{b}} \pm 0,19$ & $* *$ \\
& Cured & $1,75 \pm 0,45$ & $1,66 \pm 0,42$ & $2,01 \pm 0,70$ & $\mathrm{~ns}$ \\
& Rancid & $6,13 \pm 0,44$ & $5,97 \pm 0,38$ & $6,44 \pm 0,44$ & $\mathrm{~ns}$ \\
\hline
\end{tabular}

${ }^{A}$ statistical significance: ${ }^{* * *},{ }^{* *},{ }^{*}$ significance levels at $<0.001,<0.01,<0.05$, respectively

a, b, c, means with different superscript differ significantly

mentioned above, the number of variables is large, so we have studied whether there are statistically significant differences among variables for the three batches. The absence of significant variables is not considered in the PCA, therefore some significant variables are grouped and related to each other to reduce the number of initial inputs. Therefore, the variables considered in the PCA were: myoglobin, oleic acid (C18:1), fatty acid $n-3$, saturated fatty acids (SFA), monounsaturated fatty acids (MUFA), polyunsaturated fatty acids (PUFA), MUFA/SFA ratio, sum of the area of the amino acid derivates volatile compounds (AA), sum of the area of the lipid oxidation derivates volatile compounds (LIP), AA/LIP ratio, 3-methylbutanal, hexanal, brightness, oiliness, odor intensity, marbling, flavor intensity, cured and rancidity. All dry-cured shoulders were quite salty and this may affect the evaluation of some other sensory features, especially those related to perception after introducing the product into the mouth. 
In Figure 1, a Bi-plot PCA model is shown. In this plot, loadings and scores are plotted on the same graph. Three groups are clearly separated by quality category or class. The diagram area of the MON class is characterized by the variables: ratio AA/LIP, the peak area of 3methylbutanal, $\%$ MUFA and \% C18:1, recognized in these high quality Iberian products (Ventanas, S. et al. 2007). The area of the EXT class is characterized by the variables: content of myoglobin, \% of PUFA and $\%$ of fatty acid n-3 (which are typical of the grass diet in pigs feeding in an extensive regime). Finally, the area of the CON class is characterized by SFA, LIP and hexanal in decreasing order of quality from MON to EXT to CON.

Once the analysis of PCA was interpreted, supervised-learning pattern recognition techniques were applied, such as SIMCA, to find an operative classification role for sample discrimination.

\subsection{Soft independent modeling class analogy (SIMCA)}

The SIMCA is based on the evaluation of the principal components of each category, setting up a critical distance with probabilistic meaning and the calculation of the distance of each object from the model of each group. There are two steps involved in classification: modeling, building one PCA separate model for each class; classifying new samples, where unknown samples are then compared to the class models and if each sample fits each model, it is then determined whether the sample belongs to the corresponding class.

In SIMCA analysis there are variable results called "modelling power" (MP), which means the contribution of that variable to the class or group model; "discrimination model" (DM), which means the role of that variable to discriminate among different class models. On the other hand, there are sample results called "Si" (square root of the residual variance of the sample) which is the measurement of the distance of a sample to the modeled group, sometimes it is compared to the overall variation of the class (SO) and is the basis of the statistical criteria to decide the new sample belonging. The $\mathrm{Hi}$ (leverage) expresses how a difference in the sample can be considered from the other class members. The use of the graphical plots $\mathrm{Si}$ vs. $\mathrm{Hi}$ or Comman's plot (Si vs. Si) samples can easily be classified. Finally, the "model distance" shows how different two models are from each other, normally a model distance larger than 3 or more, shows that two models are quite different.

In our case, a PCA model for each class or group was built with the same considered variables as in the previously mentioned general PCA in order to generate a SIMCA model. This SIMCA had a model distance larger than 3 for the three models, which means a good separation between models. Based on modeling power and discrimination power the most important variables were: myoglobin, C18:1, fatty acids n-3, AA, LIP, AA/LIP, hexanal and brightness and oiliness.

The SIMCA analysis was validated with the test set. The samples of test set were classified according to the dry-cured shoulders of MON, EXT and CON classes. In Figure 2A, the Cooman's plot of the CON and MON models are shown. The CON samples are exactly classified, except CON1 which is one sample from a previous year. In the case of MON samples, all are exactly classified at $80 \%$. In Figure 2B, the Cooman's plot to CON and EXT models are shown. The classification of CON is the same as in the previous case and the classification of the EXT model is accurate for normal feeds, the special feeds are classified as belonging to any

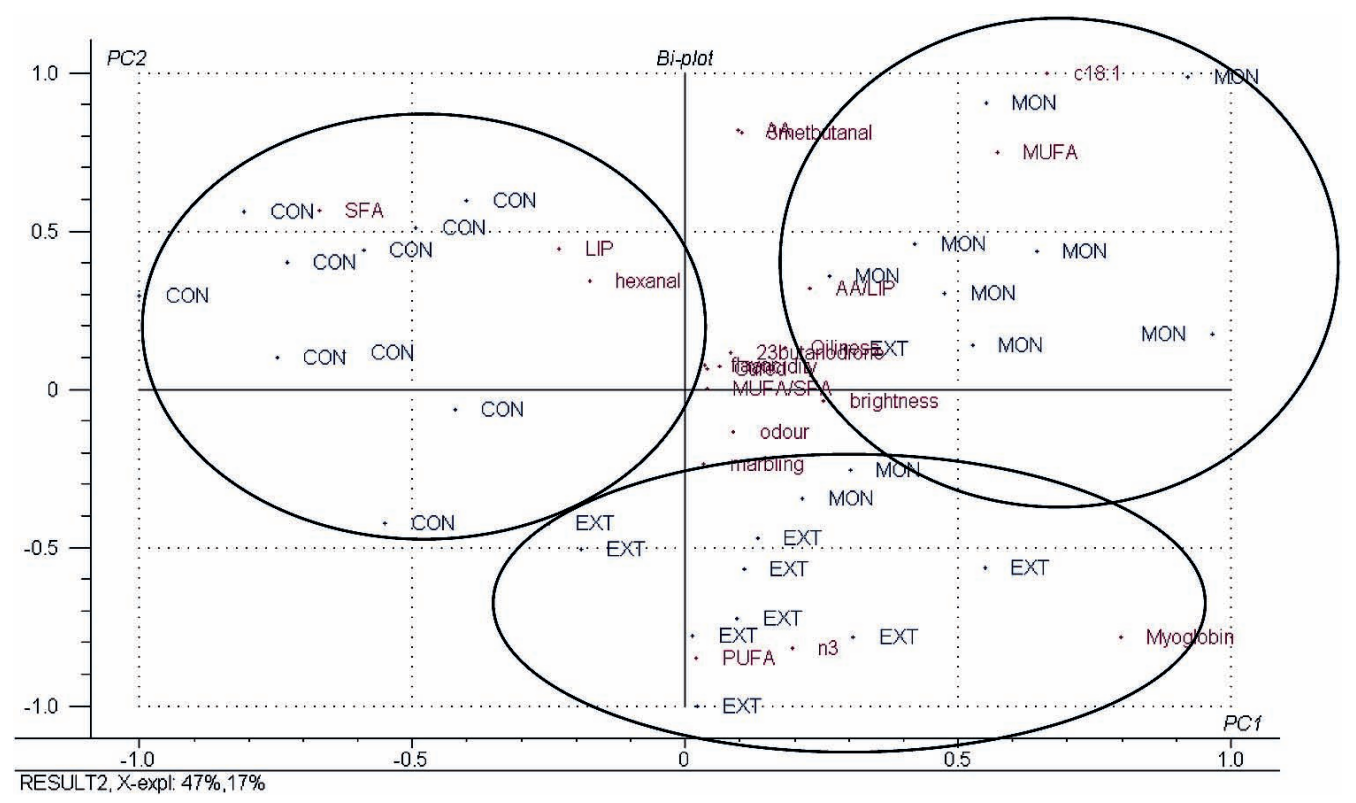

Figure 1

PCA Bi-plot shown the loadings and scores. 

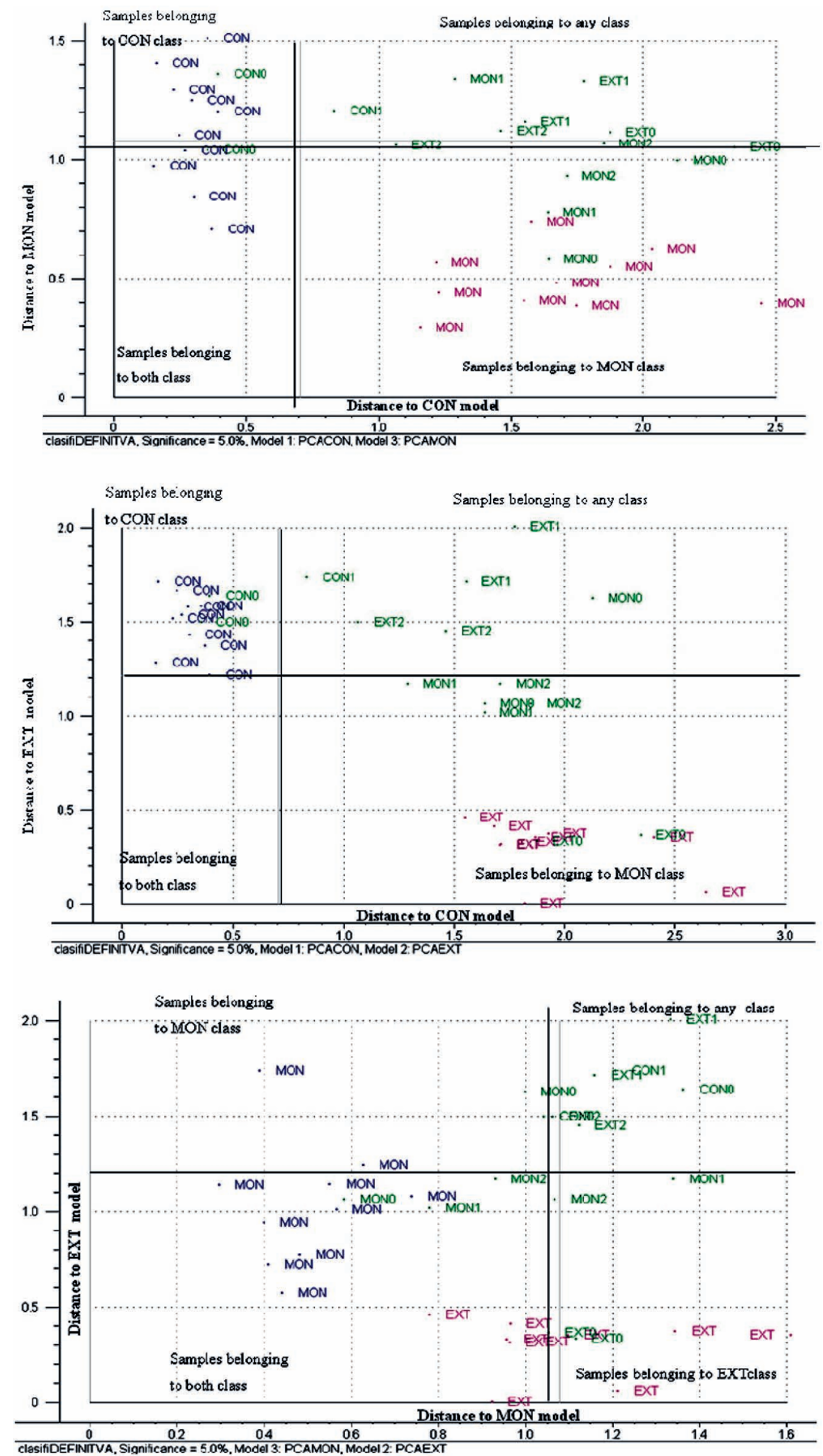

Cooman's plot for: $2 \mathrm{~A}, \mathrm{CON}$ vs MON class; $2 \mathrm{~B}, \mathrm{CON}$ vs EXT class and $2 \mathrm{C}, \mathrm{MON}$ vs EXT class. 
class. However, most of the MON samples are classified as belonging to the EXT class because of an overlapping between the MON and EXT models, as shown in Figure $2 \mathrm{C}$. In these cases, it is important to check the average, $\mathrm{Hi}$, so the $\mathrm{Si}$ vs. $\mathrm{Hi}$ plot is used instead of the Cooman's plot (Si vs. Si). In Figures $3 \mathrm{~A}$ and $\mathrm{B}$, the samples of MON and EXT are exactly classified as belonging to MON and EXT models respectively. Like the previous case, this SIMCA analysis can not classify the dry-cured shoulders from the special feed feeding pigs.

The quality evaluation of dry-cured shoulder depends on several issues that must be considered such as feeding-rearing regime, genetics, slaughtering, and time and conditions of the ripening process. Overall, the quality variability is large among dry-cured shoulders from different years. So the results obtained from the SIMCA analysis, which classifies most of the unknown quality dry-cured shoulders, belong to one of three classes, except some samples from a different year than the calibration samples, for example CON1 or samples from pigs fed with special feeds (EXT1 and EXT2). However, MON1 and MON2 (MON of a previous year than the calibration set) are accurately classified by the SIMCA analysis.

\section{CONCLUSIONS}

In this work, a protocol has been used to evaluate the quality of dry-cured Iberian shoulder. The combination of physico-chemical analysis,
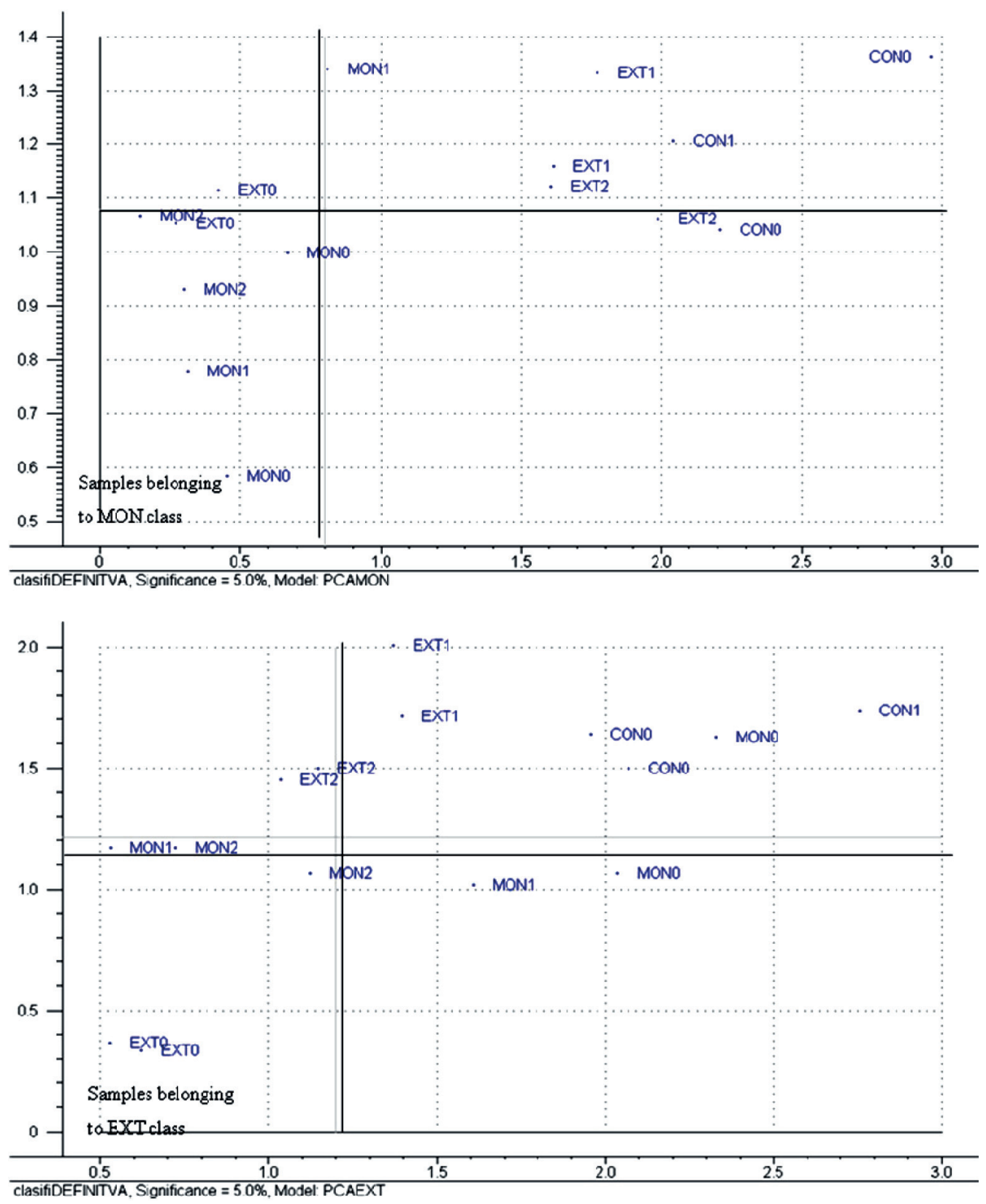

Figure 3

Si vs. Hi plot for: 3A MON model and 3B EXT model. 
classical and instrumental analysis, and sensory analysis provided a large amount of information. This information was interpreted by multivariate techniques, such as PCA, and three quality classes were clearly generated, considering only the most important variables, those that had statistically significant differences among the three groups. Therefore, a first SIMCA analysis based on a PCA model for three different quality categories had been developed to accurately classify drycured Iberian shoulders from an unknown quality class, over all the samples at the same year than calibration samples. However, dry-cured shoulder from pigs reared in extensive regime and fed with special feeds were not classified in any quality class and these samples can be considered a new quality category, which was discriminated as a special category (SPE class). Further data on drycured shoulders will be used to validate the future model with new samples.

Therefore the combinations of physic-chemical parameters and chemometrics enable accurate classification of the unknown quality class of drycured shoulder even when pigs are fed in a way that mimics the fatty-acid profile of the montanerafeedings pigs.

\section{ACKNOWLEDGEMENTS}

The authors are grateful to INIA (Contract UEX 029/09) for their financial support and Señorio Montanera for the ripening process of the dry-cured shoulder.

\section{REFERENCES}

Alonso R, Rodríguez-Estevez $\mathrm{V}$, Dominguez-Vidal $\mathrm{A}$, Ayora-Cañada MJ, Arce L, Valcarcel M. 2008. Ion mobility spectrometry of volatile compounds from Iberian pig fat for fast feeding regime authentication. Talanta. 76, 591-596.

BOE nำ 283, November 24, 2004.

Comission Regulation UE no 432/2012, establishing a list of permitted health claims made on foods, other than those referring to the reduction of disease risk and to children's development and health.

Folch J, Less M, Sloane GH. 1957. A simple method for the isolation and purification of total lipids from animal tissues. J. Biol. Chem. 226, 497-509.

Fulladosa E, Serra X, Gou P, Arnau J. 2009. Effects of potassium lactate and high pressure on transglutaminase restructured dry-cured hams with reduced salt content. Meat Sci, 82, 213-218.

Galeano-Díaz T, Duran-Meras I, Sanchez Casas J., Alexandre Franco MF, 2005. Characterization of virgin olive oils according to its triglycerides, and sterols composition by chemometrics methods. Food Control. 16, 339-347.

Gallardo E, Narváez-Rivas M, Pablos F, Jurado JM, Leon-Camacho M, Subcutaneous fat triacylglycerols profile from Iberian pigs as a tool to differentiate between intensive and extensive fattening systems. 2012 J. Agric. Food Chem. 60, 1645-1651

García G, Berdague JJ, Antequera T, Lopez-Bote C, Cordoba JJ, Ventanas J, 1991. Volatile components from dry-cured Iberian ham. Food Chem. 41, 23.

García C, Ventanas J, Antequera T, Ruiz J, Cava R, Álvarez P. 1996. Measuring sensorial quality of Iberian ham by Rasch model. J. Food Quality. 19, 397-412.

Hornsey HC. 1956. The colour of cooked cured pork. I. Estimation of the nitric oxide-haem pigments. J. Sci. Food Agric. 7, 534-540.

Jiménez-Colmenero F, Ventanas J, Toldrá F. 2010. Nutritional composition of dry-cured ham and its role in a healthy diet. Meat Sci. 8. 585-594.

Jurado JM, Ballesteros O, Alcazar A, Pablos F, Martin MJ, Vilchez JL, Navalon A. 2007. Characterization of aniseed-flavoured spirit drinks by headspace solidphase microextraction gas chromatopgraphy-mass spectrometry and chemometrics, Talanta 72, 506511

López-Bote C, Rey A, Ruiz J, Isabel B, Sanz Arias R. 1997. Effect of feeding diets high in monounsaturated fatty acids and $\alpha$-tocopheryl acetate to rabbits on resulting carcass fatty acid profile and lipid oxidation. Animal Sci. 64, 177-186.

Narváez-Rivas M, Pablos F, Jurado JM, León-Camacho M. 2010. Authentication of fattening diet of Iberian pigs according to their volatile compounds profile from raw subcutaneous fat. Anal. Bioanal. Chem. 399, 2115-2122.

Reina R, López-Buesa P, Sánchez del Pulgar J, Ventanas J. García C. 2012. Effect of IGF-II (insulinlike growth factor- II) genotype on the quality of drycured hams and shoulders. Meat Sci.. 92, 562-568.

Ruiz J, Ventanas J, Cava R. 2001. New device for direct extraction of volatiles in solid samples using SPME. $J$. Agric. Food Chem. 49, 5115.

Ruiz J, García C, Muriel E, Andrés Al. Ventanas J. 2002. Influence of sensory characteristics on the acceptability of dry-cured ham. Meat Sci. 61, 347354

Salih AM, Smith DM, Price JF, Dawson LE. 1987. ModiWed extraction 2-thiobarbituric acid method for measuring lipid oxidation in poultry. Poultry Sci. 66, 1483-1489.

SPSS (1997). SPSS for Windows: advanced statistic release. Chicago: SPSS. Unscrambler software, version 6.0 of CAMO, Trondheim, Noruega.

Ventanas J. 2006. "El jamón Iberico. De la dehesa al paladar". Ed. Mundiprensa.

Ventanas S, Ventanas J, Ruiz J, Estévez M. (2005). Iberian pigs for the development of high-quality cured products. In S. G. Pandalai (Ed.), Recent Research Developments in Agricultural and Food Chemistry. 27-53. Trivandrum, India: Research Signpost.

Ventanas S, Ventanas J, Tovar J, Garcia C, Estevez M. 2007. Extensive feeding versus oleic acid and tocopherol enriched mixed diets for the production of Iberian dry-cured hams: Effect on chemical composition, oxidative status and sensory traits. Meat Sci. $77,246-256$.

Recibido: 16/10/12 Aceptado: $26 / 1 / 13$ 